\title{
Inborn Errors of Metabolism and Osteopetrosis
}

\author{
Robert Wynn and Ansgar Schulz
}

\subsection{Inborn Errors of Metabolism}

\subsubsection{Definition and Epidemiology}

Inborn errors of metabolism (IEM) comprise a large group of inherited disease, some of which are due to disordered lysosomal, peroxisomal, or mitochondrial function and only some of which might be improved following HSCT. This review will be limited to the commoner indications reported in HSCT registries and which together account for the most transplanted IEM.

\subsubsection{Diagnosis}

Timely diagnosis is imperative in IEM since in all such diseases HSCT is better at preventing disease progression than reversing established disease manifestations.
Diagnosis is made in three ways:

- Through early recognition of disease manifestations

- Through screening of presymptomatic individuals within a known affected kindred

- Population screening for disease, such as in the neonatal period

\subsubsection{Classification (See Table 90.1)}

\subsubsection{Risk Factors}

Patient performance score at transplant predicts transplant outcome. Patients with an adverse performance score at transplant also have an inferior long-term survival as the transplant fails in advanced disease to prevent disease progression.

R. Wynn $(\bowtie)$

Blood and Marrow Transplant Unit, Royal

Manchester Children's Hospital, University of

A. Schulz

Manchester, Manchester, UK

Department of Pediatrics, University Medical Center

e-mail: robert.wynn@cmft.nhs.uk Ulm, Ulm, Germany 
Table 90.1 Classification of inborn errors of metabolism

\begin{tabular}{|c|c|}
\hline IEM & \\
\hline $\begin{array}{l}\text { Hurler syndrome, } \\
\text { MPSIH }\end{array}$ & $\begin{array}{l}\text { Hurler syndrome. This is the most severe phenotype of iduronidase } \\
\text { deficiency, a lysosomal storage disorder (LSD) which results in the } \\
\text { accumulation of glycosaminoglycans. There is progressive multi- } \\
\text { organ dysfunction including psychomotor retardation, severe skeletal } \\
\text { disease, life-threatening cardiopulmonary complications, and } \\
\text { premature death } \\
\text { HSCT prevents early death and attenuates the multi-system disease } \\
\text { manifestations as the deficient enzyme is donated by engrafted donor } \\
\text { leucocytes to host tissues ("cross-correction") }\end{array}$ \\
\hline $\begin{array}{l}\text { X-linked } \\
\text { adrenoleukodystrophy }\end{array}$ & $\begin{array}{l}\text { In this X-linked disorder, there is accumulation of very long-chain fatty } \\
\text { acids in the brain and adrenal glands arising from their defective } \\
\text { metabolism by a peroxisomal, membrane protein encoded by the ABCD1 } \\
\text { gene } \\
\text { Clinical manifestations in genetically affected boys are highly variable, } \\
\text { even within a kindred. The principle role of HSCT is to prevent } \\
\text { progression of early cerebral ALD, an inflammatory demyelinating } \\
\text { disease of childhood that is seen in about } 40 \% \text { of genetically affected } \\
\text { individuals } \\
\text { HSCT does not influence other illness such as adrenal insufficiency or the } \\
\text { later myeloneuropathy of the spinal cord }\end{array}$ \\
\hline $\begin{array}{l}\text { Metachromatic } \\
\text { leukodystrophy (MLD) }\end{array}$ & $\begin{array}{l}\text { This is a recessive LSD, and there is accumulation of sulfatides, a myelin } \\
\text { component, due to deficiency of the arylsulfatase A enzyme. There is } \\
\text { demyelination in the central and peripheral nervous systems, and clinical } \\
\text { manifestations are related to residual enzyme activity. In the late infantile } \\
\text { disease, the commonest and most severe phenotype, there is progressive } \\
\text { neurological dysfunction and early death usually by the age of } 4 \text { years } \\
\text { HSCT is ineffective in preventing progression of early presenting disease, } \\
\text { although it may have a greater impact later, attenuated disease especially } \\
\text { when applied early in the course of that illness }\end{array}$ \\
\hline
\end{tabular}

\subsubsection{Prognostic Index}

Not available

\subsubsection{First-Line Treatment (Summary)}

Multimodality therapies are usual in IEM.

- Residual disease manifestations will require management beyond the HSCT episode. This will include orthopedics, ENT, and speech therapies in lysosomal storage disorders (LSDs), as well as family and educational support in all.

- Pharmacological enzyme replacement therapy (ERT) is used in MPSI but does not correct neurological disease as it does not cross the blood-brain barrier, and alloantibody forma- tion might limit its utility in somatic disease. It is used to improve pre-HSCT performance, but it has not been shown to influence transplant outcomes.

\subsubsection{Second-Line Treatment (Summary)}

See Sect. 90.1.6., above.

\subsubsection{Autologous HSCT}

Gene-modified auto-HSCT approaches have been shown to improve outcomes in late infantile MLD as the graft delivers more enzyme than possible in a conventional HSCT. Similar approaches have been successful in X-ALD and are likely to be a significant part of the future of HSCT in IEM. 


\subsubsection{Allogeneic HSCT in MPSIH (Hurler), MLD, and X-ALD (See Table 90.2)}

Table 90.2 Main characteristics of allo-HSCT for MPSIH (Hurler), MLD, and X-ALD

\section{Indicated in}

MPSIH (Hurler) is a standard indication for HSCT

In MLD, HSCT is usually reserved for later (attenuated) forms of the disease, namely, juvenile and adult forms In X-ALD, HSCT is indicated in early cerebral inflammatory disease. Ordinarily, a genetically affected individual has serial (annual) MRI scans from early childhood, and HSCT is carried out when there are early MRI changes of demyelination (the MRI changes are scored as a Loes score)

\section{Contraindications}

Where MPSIH is diagnosed late then the opportunity for HSCT to meaningfully alter the natural history of the disease might be lost. No hard and fast rules can be applied, but often HSCT is not offered to a child presenting beyond the age of 30 months, but careful multidisciplinary assessment is required Late infantile MLD is not usually considered for HSCT. Note that such disease - if diagnosed in a timely fashionhas been shown to be markedly improved using an autologous, ex vivo HSC gene therapy approach

Advanced cerebral X-ALD is considered a contraindication to HSCT. Disease will progress through transplant. The MRI scan-derived Loes score might predict those that will benefit most from HSCT

Donor

In LSD, non-carrier MFD > MUD > carrier MFD

In LSD, UCB is frequently preferred to BM, since the post-HSCT chimerism is higher in scuh recipients, and the interval between referral and HSCT is likely shortest (rejection might be higher using UCB)

$\mathrm{PB}$ is rarely used as a donor cell source

In X-ALD, MFD > MUD

Haplo-HSCT is rarely indicated in IEM

Conditioning: standard

Engraftment is difficult in IEM. Generally reduced intensity conditioning and ex vivo TCD are associated with high rates of graft loss

MSD/MFD: IV BU (MAC AUC)/FLU $\left(160 \mathrm{mg} / \mathrm{m}^{2}\right)$

MUD: IV BU (MAC AUC)/FLU (160 mg/m²)

Conditioning: reduced toxicity

Occasionally reduced toxicity conditioning might be employed

In somatic IEM, such as Wolman or attenuated MPS: TREO/FLU $\left(160 \mathrm{mg} / \mathrm{m}^{2}\right) / \mathrm{TT}(10 \mathrm{mg} / \mathrm{kg})$

Source of SC

UCB often preferred in LSD

$\mathrm{BM}$ rather than $\mathrm{PB}$ in MUD donors

No ex vivo TCD as this is shown to contribute to graft loss

GvHD prophylaxis

MSD/MFD: ATG/Campath, CSA + MMF

MUD: ATG/Campath, CSA + MMF

MUC UCB: Proximal ATG, CSA + MMF or CSA + PRD

TRM in MPSIH

MSD: $<5 \%$

MUD: $<10 \%$

\section{OS in MPSIH}

Engrafted survival of $>80 \%$ and overall survival of $90 \%$

MAC AUC doses adjusted to achieve MAC AUC, $M S D$ match sibling donor, $M F D$ match family donor, $M U D$ much unrelated donor, $L S D$ lysosomal storage disorder, EIM inborn errors of metabolism

\subsection{Osteopetrosis}

\subsubsection{Definition and Epidemiology}

Osteopetrosis (OP) is a generic name of a number of rare single gene diseases characterized by scle- rosis of the skeleton. At least nine forms are known with different modes of inheritance and severity, which cumulatively have an incidence $\sim 1: 100,000$. The disease originates from reduced or complete lack of osteoclast function and, as a consequence, impairment of bone resorption 


\subsubsection{Diagnosis}

In addition to the obligate increased bone density of all bones (X-ray), a combination of symptoms can be found in classical infantile osteopetrosis after birth. These symptoms include characteristic changes of the head (macrocephalus, frontal bossing, choanal stenosis), vision impairment (due to narrowed foramina), hematological insufficiency (thrombocytopenia, anemia, leukocytosis), hepatosplenomegaly (due to extramedullar hematopoiesis), and hypocalcemia (with secondary hyperparathyroidism). Cave: OP is a genetical and phenotypical heterogenous disease with atypical presentations (incomplete and/or delayed onset of symptoms). In these cases, an intensive work-up including spine biopsy and cranial MRI is recommended.

\subsubsection{Classification}

\begin{tabular}{|c|c|}
\hline \multicolumn{2}{|l|}{ Osteopetrosis } \\
\hline $\begin{array}{l}\text { Infantile } \\
\text { "malignant" } \\
\text { autosomal } \\
\text { recessive OP } \\
\text { (ARO) }\end{array}$ & $\begin{array}{l}\text { Clinical symptoms in infancy, death } \\
\text { without HSCT usually in the first } \\
\text { decade of life, biallelic mutations in } \\
\text { TCIRG1, CLCN7, SNX10, TNFRSF11A } \\
\text { RANK, and FERMT3/KINDLIN-3; } \\
\text { HSCT indicated, if excluded: } \\
\text { - "Neurodegenerative OP" (all OSTM1 } \\
\text { and about half of CLCN7 cases) } \\
\text { - "Extrinsic osteoclast defects" } \\
\text { (TNFSF11/RANKL cases) }\end{array}$ \\
\hline $\begin{array}{l}\text { Intermediate } \\
\text { osteopetrosis }\end{array}$ & $\begin{array}{l}\text { Clinical symptoms in the first decade, } \\
\text { HSCT may be indicated in severe } \\
\text { forms with hematological insufficiency } \\
\text { and (imminent) visual impairment } \\
\text { Specific from: CA2 deficiency (renal } \\
\text { tubular acidosis with cerebral } \\
\text { calcifications): HSCT is rarely indicated }\end{array}$ \\
\hline $\begin{array}{l}\text { Benign } \\
\text { osteopetrosis } \\
\text { (ADO) }\end{array}$ & $\begin{array}{l}\text { M. Albers Schoenberg (monoallelic } \\
\text { CLCN7 mutations): HSCT not indicated }\end{array}$ \\
\hline
\end{tabular}

\subsubsection{Risk Factors}

There is an increased risk of pulmonary hypertension (pre and post HSCT) and SOS/VOD (post BMT). The risk of non-engraftment and rejection increases with severity of disease and age.

\subsubsection{Prognostic Index}

Not available

\subsubsection{First-Line Treatment (Summary)}

Symptomatic, steroids may be beneficial to improve hematological symptoms

\subsubsection{Second-Line Treatment (Summary)}

Not available

\subsubsection{Autologous HSCT}

Preclinical trials for gene-modified auto-HSCT for TCIRG1 defects in preparation.

\subsubsection{Allogeneic HSCT (See Table 90.3)}


Table 90.3 Main characteristics of allo-HSCT for osteopetrosis

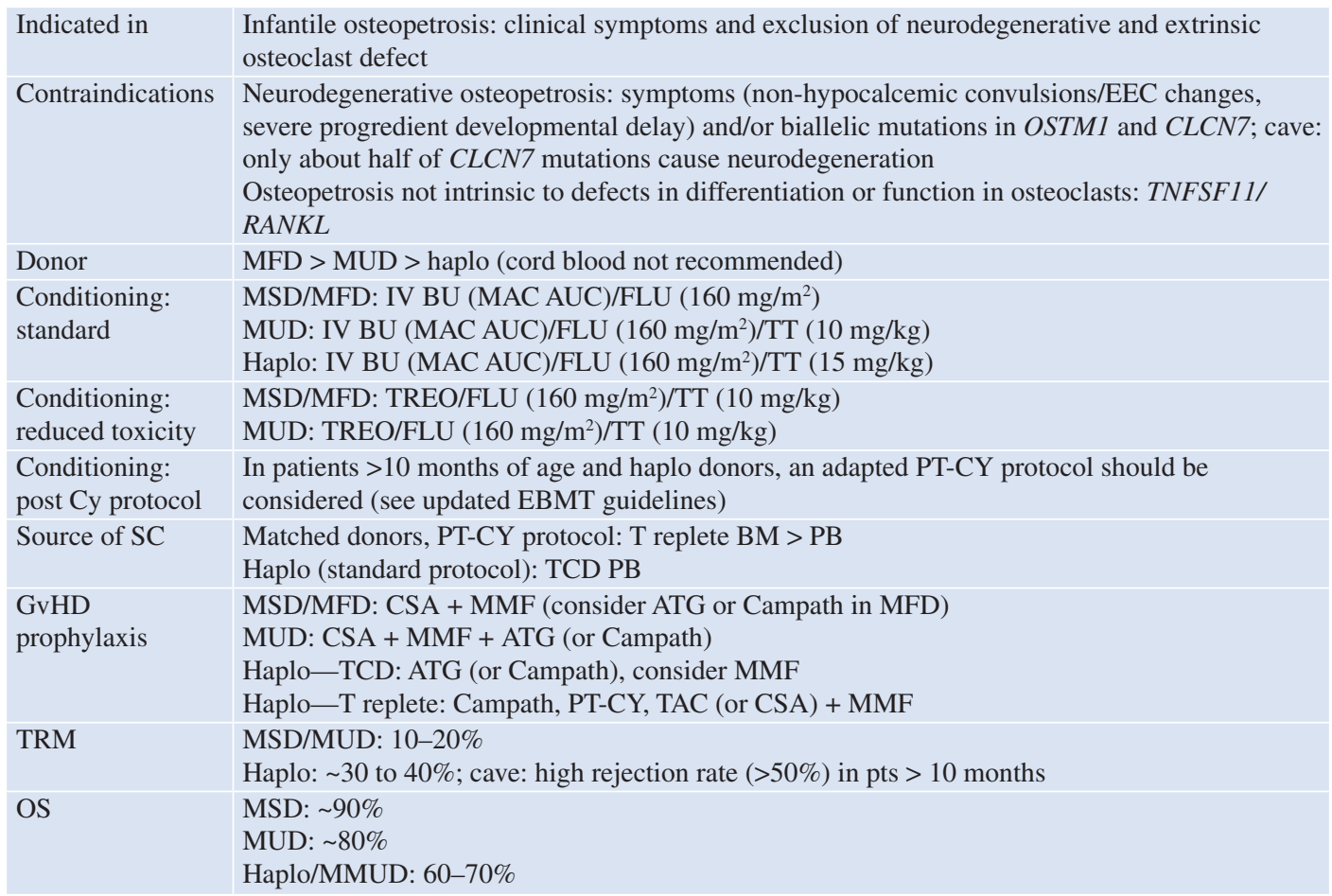

MAC AUC doses adjusted to achieve MAC AUC, MSD match sibling donor, MFD match family donor, MUD much unrelated donor, $M M U D$ mismatch unrelated donor

\section{Recommended References}

Aldenhoven M, Jones SA, Bonney D, et al. Hematopoietic cell transplantation for mucopolysaccharidosis patients is safe and effective: results after implementation of international guidelines. Biol Blood Marrow Transplant. 2015;21:1106-9.

Biffi A, Montini E, Lorioli L, et al. Lentiviral hematopoietic stem cell gene therapy benefits metachromatic leukodystrophy. Science. 2013;341: 1233158.

Boelens JJ, Wynn RF, O'Meara A, et al. Outcomes of hematopoietic stem cell transplantation for Hurler's syndrome in Europe: a risk factor analysis for graft failure. Bone Marrow Transplant. 2007;40:225-33.
Boelens JJ, Prasad VK, Tolar J, et al. Current international perspectives on hematopoietic stem cell transplantation for inherited metabolic disorders. Pediatr Clin N Am. 2010;57:123-45.

Chiesa R, Ruggeri A, Paviglianiti A, et al. Outcomes after unrelated umbilical cord blood transplantation for children with osteopetrosis. Biol Blood Marrow Transplant. 2016;22:1997-2002.

Consensus Guidelines of the EBMT and ESID at: https:// esid.org/Working-Parties/Inborn-Errors-WorkingParty-IEWP/Resources/UPDATED!-EBMT-ESIDGUIDELINES-FOR-HAEMATOPOIETICSTEMC E L L - T R A N S P L A N T AT I O N - F O R - P I/ Updated-Osteopetrosis-Consensus-Guidelines.

de Vernejoul MC, Schulz A, Kornak U. CLCN7-related osteopetrosis. 2007 Feb 12 [Updated 2013 Jun 
20]. In: Pagon RA, Adam MP, Bird TD, et al., editors. GeneReviews ${ }^{\mathrm{TM}}$. Seattle, WA: University of Washington; 2013. p. 1993-2013.

Driessen GJ, Gerritsen EJ, Fischer A, et al. Long-term outcome of haematopoietic stem cell transplantation in autosomal recessive osteopetrosis: an EBMT report. Bone Marrow Transplant. 2003;32: 657-63.

Eichler F, Duncan C, Musolino PL, et al. Hematopoietic stem-cell gene therapy for cerebral adrenoleukodystrophy. N Engl J Med. 2017;377: 1630-8.

Prasad VK, Mendizabal A, Parikh SH, et al. Unrelated donor umbilical cord blood transplantation for inherited metabolic disorders in 159 pediatric patients from a single center: influence of cellular composition of the graft on transplantation outcomes. Blood. 2008;112:2979-89.

Shadur B, Zaidman I, NaserEddin A, et al. Successful hematopoietic stem cell transplantation for osteopetrosis using reduced intensity conditioning. Pediatr Blood Cancer. 2018;65:e27010.

Sobacchi C, Schulz A, Coxon FP, et al. Osteopetrosis: genetics, treatment and new insights into osteoclast function. Nat Rev Endocrinol. 2013;9:522-36.

Teti A, Schulz A. Haematopoietic stem cell transplantation in autosomal recessive osteopetrosis. In: Rajendram R, Preedy VR, editors. Stem cells and bone diseases. Vinood Patel Editors. Boca Raton, FL: CRC Press; 2013.

Open Access This chapter is licensed under the terms of the Creative Commons Attribution 4.0 International License (http://creativecommons.org/licenses/by/4.0/), which permits use, sharing, adaptation, distribution and reproduction in any medium or format, as long as you give appropriate credit to the original author(s) and the source, provide a link to the Creative Commons license and indicate if changes were made.

The images or other third party material in this chapter are included in the chapter's Creative Commons license, unless indicated otherwise in a credit line to the material. If material is not included in the chapter's Creative Commons license and your intended use is not permitted by statutory regulation or exceeds the permitted use, you will need to obtain permission directly from the copyright holder. 